\title{
E-Procurement as a Strategic Sourcing Tool in the Beverage Industry in Zimbabwe
}

\author{
Tinashe Madzinga ${ }^{1}$, Vusumuzi Sibanda ${ }^{2}$, Shakerod Munuhwa ${ }^{2}$ \\ ${ }^{1}$ Graduate School of Business National University of Science and Technology, P.O. Box AC 939, Ascot, Bulawayo, \\ Zimbabwe \\ ${ }^{2}$ Department of Business Management BA ISAGO University P.O. BR 94 Gaborone, Botswana \\ Correspondence: Vusumuzi Sibanda, Department of Business Management BA ISAGO University P.O. BR 94 \\ Gaborone, Botswana
}

Received: June 10, 2020

doi:10.11114/bms.v6i2.4896
Accepted: June 28, $2020 \quad$ Online Published: June 29, 2020

URL: https://doi.org/10.11114/bms.v6i2.4896

\begin{abstract}
This study evaluated the impact of e-procurement as a strategic sourcing tool in the Beverage Industry in Zimbabwe. A quantitative survey of 57 respondents drawn from the key players in the Beverage Industry in Harare, Zimbabwe was conducted using a questionnaire. In line with the research objectives, descriptive statistics were calculated and cross tabulations were also performed in SPSS to produce outputs that provided answers to the research questions. The results show that through the use of e-procurement, companies are able to move towards partnership or lean supply with a smaller number of more technically proficient suppliers. The study concluded that there is a significant positive association between e-procurement and improvement in procurement efficiency. The study recommends that organisations develop adequate business processes to support e-procurement and the alignment of existing procurement processes with e-procurement procedures.
\end{abstract}

Keywords: e-procurement, procurement efficiency, strategic sourcing tool, beverage industry

\section{Introduction and Background}

In today's global competitive business environment, business leaders are increasingly shifting procurement functions from its primary role of obtaining goods and services to other roles such as value-addition and strategic decision making (Kim et al., 2015; Ross, 2016; Brandon-Jones, 2017). Due to the increasing competitive pressures, improving cost-efficiency has become the top-most priority for firms across all sectors, in particular those in the manufacturing sector (Valverde and Saadé, 2015). As a result, business leaders have turned to optimising their procurement functions with a view to reduce costs and increase efficiency. The arrival of internet and electronic procurement (e-procurement) has revolutionised procurement from its conventional mode to progressive and innovative e-commerce, e-procurement and e-supply systems.

While exploits and potentials of e-procurement have been demonstrated by studies conducted on firms in the developed world (Bromberg and Manoharan, 2015; Khorana et al., 2015; Zheng and Manoharan, 2016), Tukuta and Saruchera (2015) argue that not much has been done to explore the rate of adoption and the impact of e-procurement technologies on procurement practices and procurement performance in developing countries, especially in Zimbabwe. Therefore, this study investigated the impact of e-procurement as a strategic sourcing tool in Zimbabwe using the beverages industry as a case study.

The procurement practice gained prominence during the Industrial Revolution and the First and Second World War as supplies of raw materials and services needed to keep the factories and mines operating increased (Roshnee, 2013). In the late 1960s, the role of procurement continued to gain some relevance as the number of trained professionals increased. This according to Roshnee (2013) resulted in the transformation of the procurement into an important managerial function. Around the mid-1980s to the early 1990s procurement became more integrated into the overall corporate strategy fuelled strongly by the development of supply chain management (SCM) software solutions (Lu, 2011). At the end of the $20^{\text {th }}$ century, procurement assumed strategic functions becoming a key component in decision making process and strategic planning (De Lira, 2011). Today, procurement is considered as a strategic business function. 
Although the potential of e-procurement has already been proven in a number of studies (Bromberg and Manoharan, 2015; Khorana et al., 2015; Zheng and Manoharan, 2016), the adoption of e-procurement has progressed slowly and only a small number of organisations have demonstrated its high performance in their industries (Tukuta and Saruchera, 2015). This study therefore, sought to investigate the impact of e-procurement on strategic sourcing in Zimbabwe with the view to understand the extent to which the use of e-procurement adds value to organisations from a strategic point of view.

Organisations around the world and across all sectors have experienced unprecedented changes in the market since the new millennium. The role of procurement has also changed significantly due to the advances in information communication technologies (ICT) and the advent of the Internet (Chang and Wong, 2010; Gruenen et al., 2017). Today, web-based applications or management systems make possible various procurement-related activities to be managed electronically using virtual systems. Online purchasing, business-to-business (B2B) market places, and reverse actions provide possibilities for companies to engage in e-procurement using sophisticated applications which improve cost efficiency, supply chain transparency and reduce lead time among other benefits (Thawiwinyu and Laptaned, 2009).

While the business of procurement has changed rapidly over the past decade and more change expected in the next decade as digital technology reshapes the global economy, research conducted by Sikwila and Karedza (2016) shows that there is generally slow growth of e-procurement in Zimbabwe. The procurement process in most companies in Zimbabwe has become a costly activity for businesses over the years, often involving slow manual business procedures and even slower systematic processes for handling procurement transactions. In order to improve cost effectiveness and efficiency amidst growing competition in a tough economic environment, there is inevitable need for cost cutting measures in the supply chain and e-procurement is one such vehicle. This study therefore, sought to examine the impact of e-procurement on the performance of the Beverages Industry in Zimbabwe.

The study hypothesised that:

$\mathrm{H}_{1}$ : There is a significant association between e-procurement and reduction in procurement costs

$\mathrm{H}_{2}$ : There is a significant association between e-procurement and reduction in procurement lead time

$\mathrm{H}_{3}$ : There is a significant association between e-procurement and improvement in strategic sourcing

\section{Theoretical Frameworks}

The proposed theoretical frameworks are based on a set of variables that serve as precursors of e-procurement implementation as well as the adoption process. The conceptual models underlying the research establish a set of suppositions linking the adoption and usage of e-procurement, learning orientation implemented within the beverages sector as well as new ways to enhance the implementation and adoption of e-procurement as the future of procurement. The theories and models expounded below include Institutional Theory, Technology Acceptance Model and Theory of Diffusion of Innovation.

\subsection{The Institutional Theory}

The institutional theory is a traditional approach utilised to examine elements of public procurement (Blair, 2010). Martins and Oliveira (2009) revealed the three pillars that make institutions as regulatory, normative as well as cultural cognitive. The regulatory aspect focuses on the laws and rules that a business has to comply with. According to Dawn $e t$ al. (2010), institutions just as in business, have these pillars that make the daily activities meaningful and worth complying to. Therefore, certain activities fall as norms in the beverages industry and have settled as acceptable behaviours on the organisation. The theory brings out the idea that any institution is built on values and culture within the organisation.

Arash and Jeffrey (2010) note that a normative pillar indicates the normal way of operation in the business. Thus, the implementation, acceptance and adoption of e-procurement in the beverage companies in Zimbabwe depend on the norms and values of the business. According to Patrick and Robert (2009), cultural-cognitive evaluates the shared understanding in a business. Each business has guidelines as to the common beliefs, shared understanding and symbols. The implementation and adoption of e-procurement in any business depends on the shared understanding within the business. In relation to this study, the drive for the implementation and adoption of e-procurement within the beverages sector is hinged on desirable and appropriate fit of the system and its harmony with norms, values and beliefs. Raju (2009) insinuates that the compliance of a business to the institutional theory is heavily reliant on the perceptions and meaningfulness of any initiative.

\subsection{Technology Acceptance Model (TAM)}

Technology acceptance model (TAM) is an extension of the theory of reasoned action (TRA) model which was introduced by Davis in 1986. This theory is mainly based on the idea of technology adoption. TAM replaced TRA with 
two technologically accepted features; perceived usefulness (PU) and perceived ease of use (PEOU), which has been proven to be of significance to the adoption of technologies such as e-procurement. Many researchers have used this model to analyse key issues pertaining to the acceptance and usage of e-procurement and many have yielded positive results indicating a correlation between the incorporated variables such as PEOU and PU.

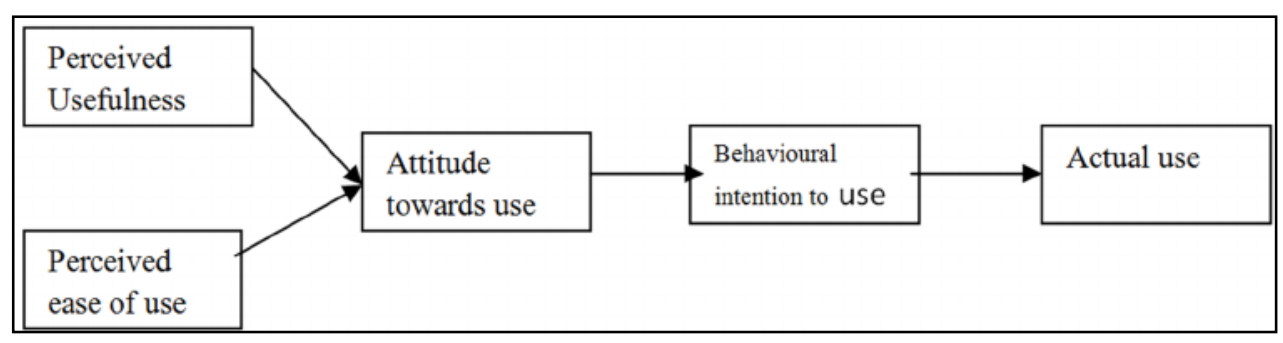

Figure 2. Technology Acceptance Model (TAM)

Source : Tella and Olasina (2014, p.50)

According to Davies (1989), perceived usefulness is the extent to which a person believes the use of a certain technology will benefit and improve his/her job performance while perceived ease of use refers to the level to which a person understands that the use of a new technology will be less complex for him/her. Jeong and Yoon (2013) studied the TAM model in their study which investigated consumer acceptance of mobile money transaction to ease business transactions, by explaining relationships that exist between variables such as perceived ease of use (PEOU), perceived usefulness (PU), perceived credibility (PC), perceived self-efficacy (PSE) and the results indicated that perceived usefulness, perceived credibility, perceived self-efficacy and PEOU have an influence in the adoption of e-commerce but the results revealed that PU had more significance than the rest of the variables in influencing businesses to adopt e-commerce, e-banking and mobile banking services.

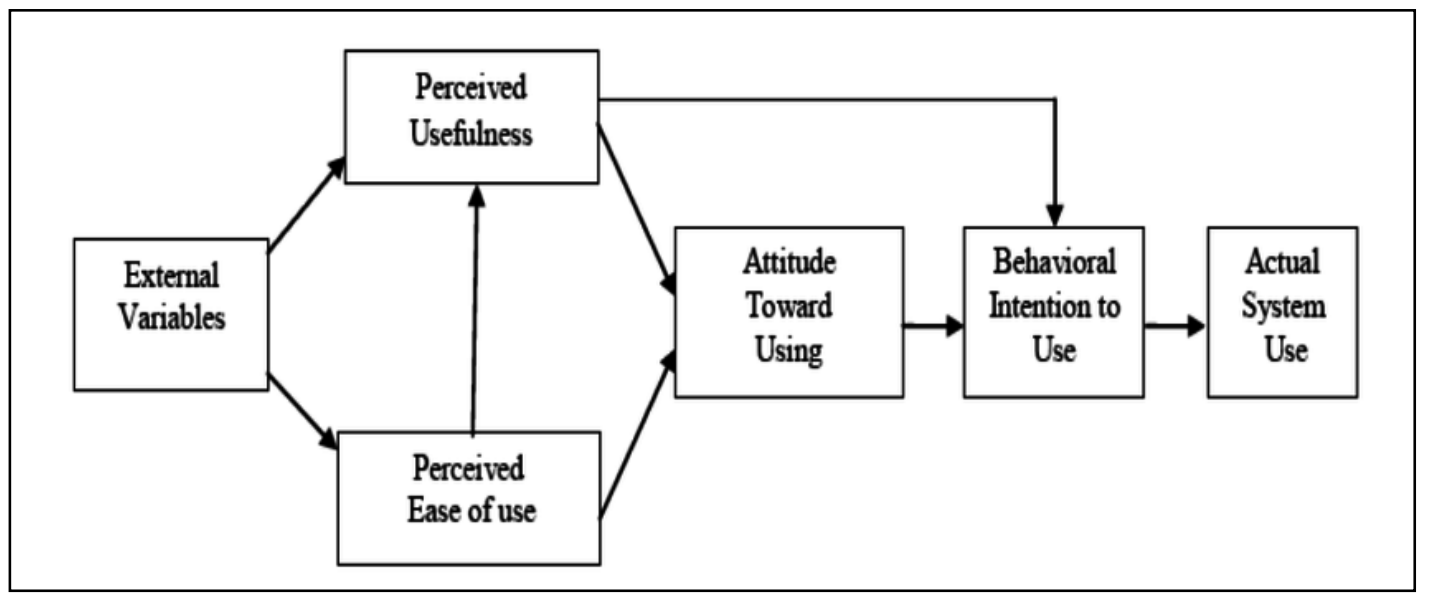

Figure 3. Extended version of TAM

Source: Davis, Bagozzi and Warshaw (1989, p.985).

According to Wojceich and Zahir (2010), constant technological developments create disruptions that may negatively affect technology acceptance in any business. The acceptance of technology in the beverages industry is dependent on the business technology PEOU, PU, Perceived Credibility (PC) and Perceived Self-efficacy (PSE). Ronchi et al. (2010) concur that the acceptance of technology should be through the acceptance of challenges that are also part of the package. Business therefore, needs to accept technology to their advantage as more advantages exist than the costs. Martins and Oliveira (2009) argue that technological developments are accepted in a business depending on factors such as availability of technology, convenience to the business and users as well as security of the technology.

\subsection{Theory of Diffusion of Innovations (DIT)}

Technology diffuses in the users and even the business in different ways, hence, the differences in the e-procurement implementation and adoption of technology. According to Turban et al. (2006), Rogers (1995) proposed that the theory of 'diffusion of innovation' was to establish the foundation for conducting research on innovation acceptance and adoption. Rogers gathered this theory from 508 studies which showed similar results when it comes to the acceptance of technology. The DIT theory expounds the process through which innovation is communicated in a social system through different channels (Rogers, 1995). 
This theory propounds that the diffusion of technology is different in every business or industry. The beverages industry readiness to embrace and use new technology depends on the acceptance of e-procurement in the sector. Kamarulzaman and Mahomed (2013) reiterate that the acceptance of technology in Fast Moving Consumer Goods (FMCGs) is anchored on the readiness of a business to support the technology. Businesses are comfortable with tried and tested e-procurement systems, hence the existence of numerous laggards in the implementation and adoption in any industry. Goodhue et al. (1995), proposed the Task-Technology Fit (TTF) model to support the adoption of technology in a business or industry. Certain technologies such as e-procurement at times are not relevant to certain activities in the beverage companies, companies become late adopters until the technology is relevant to the business. Aboelmaged (2009) observed that at times businesses take time to adopt technologies because the suppliers and other businesses are technologically lagging behind. E-procurement systems are meant to cut costs therefore, there is need to watch the effectiveness and efficiency of the system against the resources invested.

The above discussed concepts, models, applications and theories were based on literature review of different views and interpretations. The theoretical review shared reveals the theories and how they clearly fit in the study. Thus, businesses need the understanding of technology and the models that work in the business. Croom and Brandon-Jones (2007) point out that e-procurement systems need to be custom made as they are not 'one size fits all'.

According to Trkman and McCormack (2010), businesses in developing economies need to adopt e-procurement at a faster pace or keep losing to administrative costs involved with conventional procurement. Even though there is tremendous adoption of e-procurement in developed countries, Sub-Saharan countries such as Zimbabwe calculate the costs against benefits of adoption which lead to non-adoption (Barngetuny and Kimutai, 2015). Developed economies have already identified the key benefits and identified that the adoption of e-procurement is a strategic move that have future benefits in comparison to the challenges of adoption. The studies by Essig and Arnold (2006) revealed that the adoption of e-procurement overlooks the invisible boundaries that reduce exchanges between businesses. For example, the barriers of trade for small companies in Harare and those in Tsholotsho can be overcome with the adoption of e-procurement. According to Amani (2015), other African countries such as South Africa, Uganda and Nigeria are aggressively adopting e-procurement which enhances more international business transactions. Non-adoption of e-procurement also works as an inhibitor of international business such as reaching untapped markets.

E-procurement adoption has a positive impact on strategic sourcing in a business (Seurey, 2015). According to Amitt and Zott (2011), e-procurement enhances improved product quality and value addition. International B2B procurement creates and establishes e-linkages that result in strategic sourcing of both raw materials and business opportunities. Borozanov (2012) acknowledges that the shift by businesses to e-procurement is a strategic way of marketing the business. For example, anyone has access to Alibaba.com anytime, thus saving time, costs as well as effort of business marketing. Brevis and Verba (2014) argue that e-commerce gives a business a competitive advantage that is long lasting and has a future bearing on the business success. The main objective of e-procurement in any business should be enhancement of relationships that provide growth and opportunities for the business. Uba et al. (2013) assert that businesses that adopt e-procurement eliminate the costs of making new connections every time when there is need of certain products or services. Recently, the Government of Zimbabwe adopted e-governance which can be a major boost for beverage companies to adopt e-procurement.

\section{Research Methodology}

This study was conducted in Harare, the capital city of Zimbabwe in which a survey of top ten companies in the Beverage Industry in Zimbabwe was conducted on 57 respondents (Creswell and Creswell, 2017). The target population comprised operations managers, quality control managers, sales managers, finance managers and procurement managers and personnel drawn from the key players in the Beverage Industry in Harare as shown in Table 1.

Table 1. Top ten companies in the Beverages Industry in Zimbabwe based on annual revenues

\begin{tabular}{|l|l|l|}
\hline Company Name & $\begin{array}{l}\text { Revenue per year } \\
\text { US\$(millions) }\end{array}$ & $\begin{array}{l}\text { Distribution } \\
\text { managers }\end{array}$ \\
\hline Delta Beverages (Manchester Brewery) & 245 & 8 \\
\hline Delta Beverages (Coca Cola) & 230 & 5 \\
\hline Nestle Zimbabwe & 102 & 7 \\
\hline Delta Beverages (Chibuku) & 97 & 6 \\
\hline Dairiboard Zimbabwe & 93 & 7 \\
\hline Schweppes & 88 & 6 \\
\hline African Distillers & 73 & 4 \\
\hline Tanganda Tea Company & 68 & 5 \\
\hline Delta Beverages (Shumba Mahewu) & 27 & 5 \\
\hline Sparkle Beverages & 6 & 4 \\
\hline
\end{tabular}


Source: Infiniti Research Limited (2018)

A structured questionnaire consisting of mainly closed-end questions on a five-point Likert scale were administered (Patten, 2016). To boost validity, data instruments were tested through a pilot study and all the unforeseen challenges were corrected before undertaking the study. The internal consistency of the questionnaire was tested using the Cronbach's alpha and all the items on the questionnaire that contributed to the decline in the reliability were removed or rephrased in the cases where they were negatively worded (Saunders et al., 2016). The quantitative data gathered were subjected to data coding and capturing in Microsoft Office Excel (2010) and exported to SPSS Version 20. The hypotheses for this study were tested using chi-square and correlation analysis. The results were presented in tabular and graphical formats. As part of ethical considerations, the purpose of the research was clearly communicated to all the selected respondents and voluntary participation was sought through a consent form. The respondents were assured of confidentiality and anonymity and that they were free to withdraw from the study if they wished to do so (Hart, 2005; Oliver, 2010).

\section{Findings and Discussion}

\subsection{Relationship between E-Procurement and Supply Base Optimisation}

One important strategic decision in the design of an organisation's supply chain is the number of suppliers that are utilised for a given product or service. To determine the role of e-procurement as a strategic tool in the creation and management of supplier base, the respondents were asked to state their level of agreement with statements describing the effect e-procurement has on rationalisation of suppliers' lists as shown in Figure 3. The results presented in Figure 3 suggest that the adoption and implementation of e-procurement has reduced the degree of uncertainty or complexity of purchasing situation. Considering the fact that companies in the Beverages Industry purchase their supplies from a large number of suppliers, the companies continue to incur unnecessary costs ranging from administrative costs to missed opportunities to standardise the products purchased. According to Talluri et al. (2013), effective management of the sourcing process requires working more closely with fewer suppliers. As such, rationalising the supply base reduces the absolute number of transactions and the associated costs. Therefore, the adoption of e-procurement has enabled the organisations to develop an effective system of vendor appraisal and evaluation which can be used to identify suppliers with which the organisation intends to concentrate the majority of its supplies. Suppliers failing to meet the organisation's standards may be discarded, thus reducing the range of suppliers with which the buyer as well as other administrative departments has to deal with.

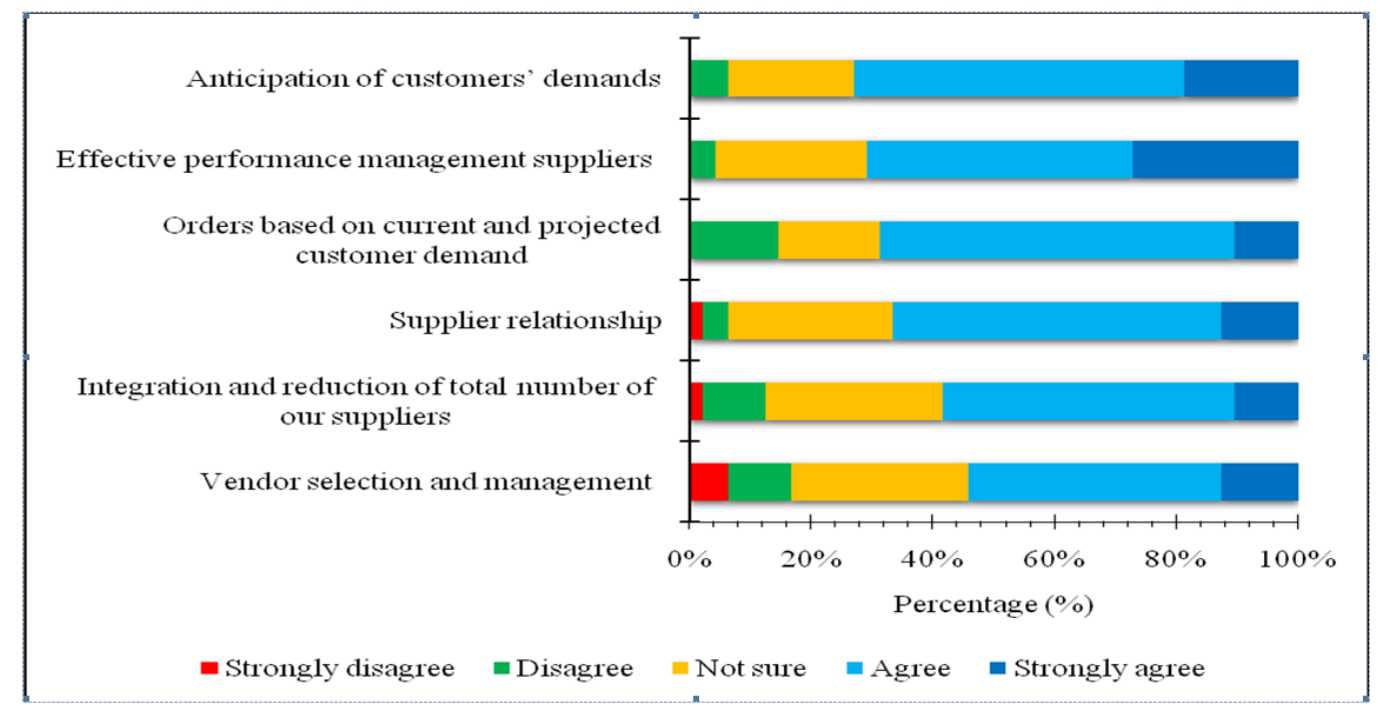

Figure 3. Effect of e-procurement on supply base optimisation

The results therefore, suggest that through the adoption of e-procurement, companies are able to regularly appraise, evaluate and rate their existing vendors. As a result, most organisations have managed to effectively integrate and reduce the total number of their suppliers based on their previous performance. The results concur with Mitra and Anshul (2012) who found that in highly competitive manufacturing sectors with tiered network sourcing structures, supply base optimisation is increasingly seen as a means of moving towards partnership or lean supply with a smaller number of more technically proficient suppliers. The findings also support Talluri et al. (2006) who suggested that e-procurement systems enable organisations to create quantifiers which monitor vendor's performance and create a 
platform to evaluate their progress in terms of buyer's strategic objective. The results also suggest that e-procurement has potential to improve the relationship between the buyers and the suppliers. This according to Mitra and Anshul (2012) is done by managing the supplier base in an effective manner by identifying and selecting suppliers for strategic long-term partnerships, involving them in early design phase of the product or new processes and providing benchmarks and continuous feedbacks.

\subsection{Influence of E-Procurement on Efficiency of the Procurement Process}

The other objective of the study was to assess the effect of e-procurement on the efficiency of procurement in the Beverages Industry. The results in Table 2 indicate that e-procurement solutions have a positive influence on the efficient performance of the supply chain management system. Through the use of e-procurement systems, procurement teams are able to manage the procurement risks and ensure that the procurement objectives are met.

Table 2. Descriptive statistics on the impact of e-procurement on efficiency of procurement

\begin{tabular}{|l|l|l|}
\hline $\begin{array}{l}\text { E-procurement system provides for a consistent and easy to follow process for } \\
\text { ordering goods and supplies. }\end{array}$ & Mean & Std. Dev \\
\hline E-procurement system ensures that there is minimum disruption of services & 3.67 & 0.875 \\
\hline E-procurement system reduces the cost of purchasing and the time it takes & 3.65 & 0.930 \\
\hline $\begin{array}{l}\text { E-procurement system ensures that the quality of service and costs always match the } \\
\text { value for money }\end{array}$ & 3.65 & 1.000 \\
\hline E-procurement system ensures that supplies are within cost limits & 3.63 & 0.866 \\
\hline $\begin{array}{l}\text { E-procurement system competently manages the procurement risks and ensures that } \\
\text { the procurement objectives are met }\end{array}$ & 3.62 & 0.898 \\
\hline E-procurement system ensures that all procurements are received & 3.52 & 1.010 \\
\hline $\begin{array}{l}\text { Our procurement system ensures that the goods and supplies that we receive are of } \\
\text { appropriate quality }\end{array}$ & 3.50 & 0.968 \\
\hline $\begin{array}{l}\text { E-procurement system ensures that performance targets on value for money obtained } \\
\text { and cost savings are always achieved }\end{array}$ & 3.46 & 0.874 \\
\hline The procurement function within my organisation is responsive to my ad hoc needs. & 3.40 & 0.939 \\
\hline E-procurement system is good at negotiating good prices & 3.38 & 0.914 \\
\hline $\begin{array}{l}\text { E-procurement system ensure that the company procurement needs are met, but not } \\
\text { exceeded }\end{array}$ & 3.25 & 0.887 \\
\hline
\end{tabular}

These findings are in tandem with the findings of Eadie et al. (2010) who concluded that being a lean channel for communication; e-procurement is a rapid efficient method of finding and connecting with new suppliers. Similar results were also reported by Matunga et al. (2013) who found that by adopting e-procurement, staff has sufficient time to engage on strategic issues of procurement. According to Matunga et al. (2013), the time wasted in moving from one town or country to another to look for a potential supplier or buyer is greatly reduced when an organisation adopts e-procurement since with a click of a button, sourcing information can readily be obtained on the internet.

\subsection{Hypothesis Testing}

$\mathrm{H}_{1}$ : There is a significant association between e-procurement and price reduction. To test this hypothesis, Chi-square tests were used. Statements related to the association between e-procurement and cost reduction were subjected to Chi-square tests. The results on all the six parameters show that at $\alpha=0.5$, there is a significant relationship between e-procurement and reduction in costs.

$\mathrm{H}_{2}$ : There is a significant association between e-procurement and a reduction in procurement lead time

The hypothesis was tested using Chi-square test. Three statements from the questionnaire linked to the aspect were used and the results are shown in Table 3 
Table 3. Association between e-procurement and reduction in procurement lead time

\begin{tabular}{|l|l|l|l|}
\hline & $\begin{array}{l}\text { Technology is used to make } \\
\text { the process of ordering and } \\
\text { paying for goods easy and } \\
\text { efficient }\end{array}$ & $\begin{array}{l}\text { The main driving force to the adoption } \\
\text { and implementation of e-procurement } \\
\text { was the need to reduce time spent on } \\
\text { procurement }\end{array}$ & $\begin{array}{l}\text { The current procurement } \\
\text { system reduces the cost of } \\
\text { purchasing and the time it } \\
\text { takes }\end{array}$ \\
\hline Chi-Square & $49.917^{\mathrm{a}}$ & $18.167^{\mathrm{b}}$ & $22.167^{\mathrm{b}}$ \\
\hline Df & 4 & 3 & 3 \\
\hline $\begin{array}{l}\text { Asymp. } \\
\text { Sig. }\end{array}$ & .000 & .000 & .000 \\
\hline a. 0 cells $(0.0 \%)$ have expected frequencies less than 5. The minimum expected cell frequency is 9.6. \\
\hline b. 0 cells $(0.0 \%)$ have expected frequencies less than 5. The minimum expected cell frequency is 12
\end{tabular}

As shown in Table 3, at 5\% significance level, there is sufficient evidence that the adoption of e-procurement has a significant effect on reducing the procurement lead time.

The third hypothesis inferred a significant association between e-procurement and improvement in strategic sourcing. The Spearman Rank Correlation coefficient was used to measure the relationship between the key drivers of e-procurement and their influence on strategic sourcing in the Beverages Industry. Table 4 presents the Spearman's Rank Correlation coefficients.

Table 错误!文档中没有指定样式的文字。. Spearman Rank Correlation coefficient

\begin{tabular}{|l|l|l|l|l|l|}
\hline & $\begin{array}{l}\text { Supply market } \\
\text { intelligence }\end{array}$ & $\begin{array}{l}\text { Costs } \\
\text { efficiency }\end{array}$ & $\begin{array}{l}\text { Appraisal of } \\
\text { suppliers }\end{array}$ & $\begin{array}{l}\text { Supply base } \\
\text { optimisation }\end{array}$ & $\begin{array}{l}\text { Strategic } \\
\text { sourcing }\end{array}$ \\
\hline $\begin{array}{l}\text { Supply market } \\
\text { intelligence }\end{array}$ & 1.000 & & & & \\
\hline Cost efficiency of & 0.546 & 1.000 & & & \\
\hline $\begin{array}{l}\text { Appraisal } \\
\text { suppliers }\end{array}$ & $0.618^{* *}$ & $0.544^{* *}$ & 1.000 & & \\
\hline $\begin{array}{l}\text { Supply base } \\
\text { optimisation }\end{array}$ & 0.417 & 0.134 & 0.508 & 1.000 & \\
\hline Strategic sourcing & $0.410^{* *}$ & $0.374^{* *}$ & $0.475^{* *}$ & $0.226^{* *}$ & 1.000 \\
\hline
\end{tabular}

**. Correlation is significant at the 0.01 level (2-tailed)

The results in Table 4 show that there is a positive correlation between the key drivers of e-procurement namely: supply market intelligence; cost efficiency; appraisal of suppliers; supply base optimisation and strategic sourcing. The findings are consistent with the findings of Eadie et al. (2010) who concluded that e-procurement has a positive effect on market intelligence and the procurement decisions made on the basis of that intelligence. According to Eadie et al. (2010), strategic sourcing cannot be made without market intelligence. The results are also in line with Krmac (2011) who established that e-procurement improves access to information. E-procurement enables faster data preparation and transmission times. Handfield (2006) also shows that market intelligence functions and tools enable strategic sourcing by combining on-going monitoring, research and analysis with deep needs assessment, a future focus and problem solving. The positive relationship between supplier evaluation and strategic sourcing was also reported by Pikousova and Prusa (2013) who reported that measuring supplier performance is essential to ensure a well-functioning supply chain and company competitiveness. Understanding supplier performance will both prevent risk and improve cooperation.

\section{Conclusion}

\subsection{E-procurement, Supply Base Optimisation and Efficiency}

\subsubsection{Relationship between E-Procurement and Supply Base Optimisation}

The adoption of e-procurement has enabled companies in the Beverages Industry to develop an effective system of vendor appraisal and evaluation which can be used to identify suppliers with which the organisation intends to concentrate the majority of its supplies. Implementation of e-procurement has enabled most of the companies to integrate and reduce the total number of suppliers. Through the use of e-procurement, the procurement department is able to identify and discard suppliers failing to meet prescribed standards thereby reducing the range of suppliers with which the buyers as well as other administrative departments have to deal with. By rationalising the supply base through e-procurement, the majority of companies in the Beverages Industry have managed to reduce the absolute number of 
administrative handiwork and the number of transactions thereby effectively managing the sourcing process. Considering the fact that companies in the Beverages Industry are used to purchasing their supplies from a large numbers of suppliers, supply base optimisation through use of e-procurement has enabled the companies to cut unnecessary costs ranging from administrative costs to missed opportunities to standardise the products purchased. Supply base optimisation is increasingly seen as a means of moving towards partnership or lean supply with a smaller number of more technically proficient suppliers. The use of e-procurement solutions has also enabled companies in the Beverages Industry to effectively anticipate customers' demand which has a bearing on whether they should increase or decrease their supply base. Therefore, the adoption and implementation of e-procurement has reduced the degree of uncertainty or complexity of purchasing transactions.

\subsubsection{Influence of E-Procurement on Efficiency of the Procurement Process}

The results revealed that e-procurement solutions have a positive effect on the performance of the supply chain management systems. Through the use of e-procurement systems, the procurement team is able to competently manage the procurement risks and ensure that the procurement objectives are met. The adoption of e-procurement solutions has enabled staff to have ample time to engage on strategic issues of procurement thereby making e-procurement an efficient method of finding and connecting with new reliable suppliers. The study also established that e-procurement saves time as a potential supplier could be scouted for through the click of a button.

\subsection{Recommendations}

Based on the study findings, the following recommendations are proffered:

Companies in the Beverages Industry are recommended to regularly appraise, evaluate and rate their existing vendors. The majority of supplies must be concentrated on the best performing suppliers and those failing to meet standards must be discarded. Furthermore, to improve the role of e-procurement as a strategic sourcing tool, procurement as a function should be provided with tools that support continuous input to an organisation's strategic sourcing decision making processes, as well as manage key relationships with suppliers. The study also recommends that the procurement function must be routinely included in cross-functional teams, in order to access information on changes in supply markets.

\subsection{Areas for Future Studies}

Since this study was confined to the Beverages Industries, further studies must be done to explore sectorial differences in the adoption of e-procurement. Also, given that several studies on e-procurement and strategic sourcing have been conducted in the private sector, there is need to evaluate the impact of e-procurement as a strategic tool on the performance of supply chain in the public sector in Zimbabwe.

\section{References}

Aboelmaged, M. G. (2009). An empirical analysis of ERP implementation in a developing country: toward a generic framework. International Journal of Enterprise Network Management, 3(4), 309-331.

Amani, F. (2015). Organizing ERP research: a knowledge-centric approach. Journal of Enterprise Information Management, 29(6), 919-940.

Amit, R., \& Zott, C. (2011). Crafting business architecture: The antecedents of business model design. Strategic Entrepreneurship Journal, 9(4), 331-350.

Arash, A., \& Jeffrey, T. (2010). Effective benchmarking of innovation adoptions: A theoretical framework for e-procurement technologies. Benchmarking: An International Journal, Emerald Publishers, 17(4), 472-490. https://doi.org/10.1108/14635771011060558

Bagozzi, R. P. (2007). The legacy of the technology acceptance model and a proposal for a paradigm shift. Journal of the Association for Information Systems, 8(4).

Barngetuny, D. C., \& Kimutai, G. (2015). Effects of e-procurement on supply chain management performance in Elgeyo-Marakwet County. International Academic Journal of Procurement and Supply Chain Management, 1(5), 99-120.

Blair, S. (2010). The problem of discussions with tenders under the EC procurement directives: the current law and the case of reform. Private Procurement Law Review, 7(3), 65-82.

Borozanov, O. (2012). How a strong Procurement Function can help Banks cut costs. Amsterdam: Oracle's Industry Strategy and Insight Program.

Brandon-Jones, A. (2017). E-procurement quality from an internal customer perspective: Construct development, refinement, and replication using a mixed-methods approach. International Journal of Operations \& Production 
Management, 37(12), 1741-1772.

Brevis, T., \& Verba, M. J. (Eds). (2014). Management principles: a contemporary edition for Africa. Juta and Company Ltd.

Bromberg, D., \& Manoharan, A. (2015). E-procurement implementation in the United States: Understanding progress in local government. Public Administration Quarterly, 360-392.

Chang, H. H., \& Wong, K. H. (2010). Adoption of e-procurement and participation of e-marketplace on firm performance: Trust as a moderator. Information and Management, 47(5), 262-270.

Creswell, J. W., \& Creswell, J. D. (2017). Research design: Qualitative, quantitative, and mixed methods approaches. Sage publications.

Croom, S., \& Brandon-Jones, A. (2007). Impact of e-procurement: experiences from implementation in the UK public sector. Journal of Purchasing and Supply Management, 13(4), 294-303.

Davis, F. D. (1989). Perceived usefulness, perceived ease of use, and user acceptance of information technology. MIS quarterly, 319-340. https://dl.acm.org/doi/10.2307/249008

Davis, F. D., Bagozzi, R. P., \& Warshaw, P. R. (1989). User acceptance of computer technology: a comparison of two theoretical models. Management Science, 35(8), 982-1003.

De Lira, J. M. R. (2011). The strategic role of the purchasing function-strategic alignment. Master of Science Thesis Stockholm: KTH Industrial Engineering and Management. SE-100 44 STOCKHOLM

Eadie, R., Perera, S., \& Heaney, G. (2010). A cross-discipline comparison of rankings for e-procurement drivers and barriers within UK construction organisations. Journal of Information Technology in Construction, 15, 217-233.

Essig, M., \& Arnold, U. (2006). Electronic procurement in supply chain management: an information economics-based analysis of electronic markets. Journal of Supply Chain Management, 37(3), 43-49.

Goodhue, D. L., \& Thompson, R. L. (1995). Task-technology fit and individual performance. MIS quarterly, 213-236.

Gruenen, J., Bode, C., \& Hoehle, H. (2017). Predictive Procurement Insights: B2B Business Network Contribution to Predictive Insights in the Procurement Process Following a Design Science Research Approach. In International Conference on Design Science Research in Information Systems (pp. 267-281). Springer, Cham.

Handfield, R. (2006). Supply market intelligence: A managerial handbook for building sourcing strategies. CRC Press.

Hart, C. (2005). Doing your masters dissertation. Thousand Oaks: Sage Publishers.

Infiniti Research Limited. (2018). Beverage Industry in Zimbabwe Market Research and Statistics. Retrieved from https://www.reportlinker.com/ci02013/Beverage.html/coverage/Africa:Zimbabwe

Jeong, B. K., \& Yoon, T. E. (2013). An empirical investigation on consumer acceptance of mobile banking services. Business and Management Research, 2(1), 1-21.

Kamarulzaman, N. H., \& Mohamed, Z. A. (2013). Application of e-procurement technologies for selecting suppliers of agro-based SMEs in Malaysia. International Journal of Economics and Management, 7(1), 45-66.

Khorana, S., Ferguson-Boucher, K., \& Kerr, W. A. (2015). Governance Issues in the EU's e-Procurement Framework. Journal of Common Market Studies, 53(2), 292-310.

Kim, M., Suresh, N. C., \& Kocabasoglu-Hillmer, C. (2015). A contextual analysis of the impact of strategic sourcing and e-procurement on performance. Journal of Business and Industrial Marketing, 30(1), 1-16.

Krmac, E. V. (2011). Intelligent Value Chain Networks: Business Intelligence and other ICT Tools and Technologies in Supply/Demand Chains. In Supply Chain Management-New Perspectives. InTech.

Lu, D. (2011). Fundamentals of supply chain management. Bookboon.

Martins, M., \& Oliveira, T. (2009). Determinants of e-commerce adoption by small firms in Portugal. In Proceedings of the 3rd European Conference on information management and evaluation, 328-338.

Matunga, D. A., Nyanamba, S. O., \& Okibo, W. (2013). The Effect of E-Procurement Practices on Effective Procurement in Public Hospitals: A Case of KISII Level 5 Hospital. American International Journal of Contemporary Research, 3(8), 103-115

Mitra, S., \& Anshul, K. (2012). Vendor Base Rationalization: An Opportunity to View Supply Chain Through a Single Pane of Glass. IUP Journal of Supply Chain Management, 9(4).

Oliver, P. (2010). The student's guide to research ethics. McGraw-Hill Education (UK). 
Onwuegbuzie, A. J., \& Collins, K. M. (2007). A typology of mixed methods sampling designs in social science research. The Qualitative Report, 12(2), 281-316.

Pearcy, D. H., Parker, D. B., \& Giunipero, L. C. (2008). Using Electronic Procurement to Facilitate Supply Chain. American Journal of Business, 23(1), 23-35.

Pikousova, K., \& Prusa, P. (2013). Supplier evaluation: The first step in effective sourcing. Journal of Transport and Supply Chain Management, 7(1), 1- 4.

Raju, S. (2009). E-procurement The Future of Supply Chain. Head-Technology and Research Group.

Rogers, E. M. (1995). Lessons for guidelines from the diffusion of innovations. Joint Commission Journal on Quality and Patient Safety, 21(7), 324-328.

Ronchi, S., Brun, A., Golini, R., \& Fan, X. (2010). What is the value of an IT e-procurement system? Journal of Purchasing and Supply Management, 16(2), 131-140.

Roshnee, M. (2013). Making procurement performance count - part 1: Evolution of procurement. Financial Savings Management.

Ross, D.F. (2016). Introduction to e-supply chain management: engaging technology to build market-winning business partnerships. CRC Press.

Saunders, M. L., Lewis, P., \& Thornhill, A. (2016). Research methods for business students, 5th Edition.

Seurey, T. T. (2015). Effects of Strategic Procurement on Competitiveness of Commercial Banks Operating in Kenya. A Case Study of Standard Chartered Bank Limited Kenya.

Sikwila, M. N., \& Karedza, G. (2016). Electronic Procurement and Cost Saving in the Fast-Moving Consumer Goods: A Case Study of Retail Sector in Zimbabwe. Mediterranean Journal of Social Sciences, 7(4), 122. http://doi:10.5901/mjss.2016.v7n4p122

Talluri, S., DeCampos, H. A., \& Hult, G. T. M. (2013). Supplier rationalization: A sourcing decision model. Decision Sciences, 44(1), 57-86.

Tella, A., \& Olasina, G. (2014). Predicting users' continuance intention toward e-payment system: An extension of the technology acceptance model. International Journal of Information Systems and Social Change, 5(1), 47-67.

Thawiwinyu, K., \& Laptaned, U. (2009). The impact of strategic sourcing and e-procurement on supply chain performance management. China-USA Business Review, 8(8), 8-2 5

Trkman, P., \& McCormack, K. (2010). Estimating the benefits and risks of implementing e-procurement. IEEE Transactions on Engineering Management, 57(2), 338-349.

Tukuta, M., \& Saruchera, F. (2015). Challenges facing procurement professionals in developing economies: Unlocking value through professional international purchasing. Journal of Transport and Supply Chain Management, 9(1), $1-9$.

Turban, E., King, D., Lee, J., Warkentin, M., \& Chung, M. H. (2006). E-commerce: A managerial perspective. Low Price Edition, pp.180-183

Uba, Z., Sharifai, M. G., Mubaraka, C. M., Agaba, L., \& Principal, D. (2013). E-Procurement and Performance of Service Organizations in Uganda. European Journal of Business Management, 5(12), 46-50

Valverde, R., \& Saadé, R. G. (2015). The effect of E-supply chain management systems in the north American electronic manufacturing services industry. Journal of Theoretical and Applied Electronic Commerce Research, 10(1), 79-98.

Zheng, Y., \& Manoharan, A. P. (2016). The Influence of Government Capacity on E-Services Diffusion at Municipal Level in New Jersey. International Journal of Public Administration in the Digital Age, 3(4), 1-9.

\section{Copyrights}

Copyright for this article is retained by the author(s), with first publication rights granted to the journal.

This is an open-access article distributed under the terms and conditions of the Creative Commons Attribution license which permits unrestricted use, distribution, and reproduction in any medium, provided the original work is properly cited. 